\title{
PRISPÔSOBOVANIE MARKETINGOVÉHO MANAŽMENTU PODNIKATELSKÝCH SUBJEKTOV MÄSOSPRACUJÚCEHO PRIEMYSLU VNÚTORNÉMU TRHU EU
}

\author{
Ladislav Mura
}

\section{Klíčová slova:}

marketing, manažment, podnikatel’ský subjekt, prispôsobovanie, mäsospracujúci priemysel, trh EÚ

\section{Key words:}

marketing, management, enterprise subject, adaptation, meat-processing industry, EU market

\begin{abstract}
Abstrakt
Trh s agropotravinárskymi produktmi prešiel za uplynulé desat'ročie značnými zmenami a najviac ho ovplyvnili transformácia vlastníckych vzt’ahov a prienik nadnárodných spoločností do potravinárskej výroby. V mäsospracujúcom priemysle majú podniky až na niekol'ko výnimiek charakter malého a stredného podnikania. Obstát' v ostrom konkurenčnom boji si vyžaduje efektívne uplatňovat' princípy marketingového manažmentu. Na nové podmienky spoločného trhu EÚ sa museli prispôsobit' aj mäsospracujúce podniky. Predkladaný článok skúma hlavné oblasti prispôsobovania marketingového manažmentu uvedených podnikov na podmienky vnútorného trhu únie. Tento trh najviac formujú prehlbujúca sa globalizácia a integrácia v ekonomike sveta. Poukážeme tiež na faktory úspešného prispôsobovania marketingového manažmentu na náročné podmienky zjednoteného trhu Európskej únie.
\end{abstract}

\begin{abstract}
The agricultural goods market went through fundamental changes throughout the last ten years. The biggest influence came by the transformation of ownership and the international companies penetration into the food-processing business. The meat processing industry can be characterized as one that almost consists of small and medium enterprises only. To survive this sharp competitive environment requires an effective usage of marketing management priciples. The meat processing industry has to adapt to the new conditions of the common EU market as well. This article is analysing the main fields of marketing management adaptation of enterprises to the conditions of EU market. This market is mainly affected by a high level of globalization and a strong integration in world economics. Shown are the success factors for adapting marketing management into the difficult conditions of the unified European Union market.
\end{abstract}

\section{Úvod}

Postupujúca globalizácia, medzinárodná ekonomická interdependencia vytvárajú nové podnikatel'ské príležitosti a posúvajú podnikanie do teritoriálne a kvalitatívne nových dimenzií. V súčasnom ostrom konkurenčnom boji zaujímajú popredné miesto schopnosti úspešne a rýchlejšie ako konkurenčné subjekty aplikovat' výsledky výskumu a technologického pokroku a inováciami v produktoch a službách predvídat' spotrebitel'ove potreby. Prispôsobovanie sa novým podmienkam trhu predpokladá v oblasti marketingového manažmentu vol'bu vhodnej marketingovej a konkurenčnej stratégie tak, aby jej aplikácia 
viedla $\mathrm{k}$ budovaniu silnej pozície na trhu a zabezpečila perspektívu d’alšieho rozvoja podnikania.

Podmienky na trhu s agropotravinárskymi produktmi sa za uplynulé dve desat'ročia dynamicky menili. Najviac bol trh ovplyvnený transformáciou vlastníckych vzt’ahov v podnikovej základni, neskôr prienikom zahraničných investorov do jednotlivých odborov potravinárskeho priemyslu. Formovanie podnikatel'ského prostredia výrazne ovplyvnil aj vstup Slovenska do Európskej únie, s potrebou adaptovat' sa novým podmienkam zjednoteného trhu. Podnikatel'ské subjekty sa prispôsobovali konkurenčnému prostrediu, menili vnútropodnikové riadenie, zvyšovali ekonomickú efektívnost' výroby a kvalitu produktov, zavádzali inovácie. Zvlášt' pre odbory potravinárskeho priemyslu bolo dôležité modernizovat' technologické vybavenie, aby podniky vyhovovali náročným kvalitatívnym a hygienickým štandardom, ktoré si vyžadujú európske normy. Uvedené aspekty bolo nutné premietnut' aj do prispôsobovania marketingového manažmentu konkrétnych podnikov.

Nové podmienky, pre ktoré je charakteristický vysoko rozvinutý trh s prevahou ponuky nad dopytom, relatívna nasýtenost' v základných potrebách spotrebitel’ov vyvolali požiadavku prispôsobovania sa ponuky podnikov potrebám spotrebitel'ov. Marketingové riadenie je jedným zo základných predpokladov efektívneho a úspešného fungovania podniku. Manažéri slovenských podnikov si uvedomujú, že ich spoločnosti pôsobia v náročnom trhovom prostredí. [5]

\section{Materiál a metódy}

Na základe skúmania procesu prispôsobovania marketingového manažmentu v analyzovanej vzorke mäsospracujúcich podnikov v období meniacich sa trhových podmienkach v horizonte rokov 2002 až 2006 je hlavným ciel’om článku definovat' rozhodujúce faktory úspešného prispôsobovania marketingového manažmentu na nový zjednotený vnútorný trh Európskej únie. Parciálnymi ciel'mi sú: analyzovat' marketingový manažment v skúmaných podnikoch v období pred vstupom SR do Európskej únie, analyzovat' marketingový manažment v skúmaných podnikoch vobdobí po vstupe SR do Európskej únie, charakterizovat' podnikatel'skú činnost' mäsospracujúcich podnikov na domácom a zahraničnom trhu, uskutočnit' SWOT analýzu analyzovaných podnikov a vyšpecifikovat' - navrhnút' faktory úspešného marketingového riadenia skúmaných mäsospracujúcich podnikov.

Objektom skúmania sú najväčšie a najvýznamnejšie podniky mäsospracujúceho priemyslu na Slovensku. Výskumnú vzorku tvorili podnikatel'ské subjekty, ktoré svojou produkciou pokrývajú 74,8\% ponuky všetkých mäsospracujúcich podnikov na Slovensku.

Splnenie vytýčeného ciel'a si vyžiadalo uskutočnit' primárny výskum medzi podnikmi mäsospracujúceho priemyslu. Prvotné informácie a údaje boli získané technikou dotazníka, riadeným rozhovorom s vrcholovým manažmentom podnikov a panelovou diskusiou za účelom definovania kl’účových faktorov vedúcich $\mathrm{k}$ úspešnému prispôsobovaniu marketingového manažmentu. Vzhl'adom $\mathrm{k}$ citlivosti údajov, ktoré boli potrebné k spracovaniu článku, budeme jednotlivé podnikatel'ské subjekty označovat' všeobecným označením „,podnik 1“, „podnik 2“ a podobne. Doplňujúcimi prameňmi informácií boli sekundárne zdroje, najmä Správy o pol’nohospodárstve a potravinárstve SR (,Zelená správa“), analytické práce Pôdohospodárskej platobnej agentúry, analytické a interné materiály Ministerstva pôdohospodárstva SR ako aj výstupy z riešených výskumných úloh v danej problematike. 
Pri spracovaní primárnych a sekundárnych informácií boli použité logické metódy, vybrané matematicko - štatistické metódy, metódy deskriptívnej štatistiky, SWOT analýza. Závislosti medzi jednotlivými znakmi boli kvantifikované a overované na hladine významnosti $\alpha=0,05$ prostredníctvom chí-kvadrát testu a korelačných koeficientov. Interpretácia výsledkov je prostredníctvom ,p-hodnoty“.

\section{Teoretické východiská}

Podmienky podnikatel'skej činnosti v agropotravinárskom komplexe výrazne ovplyvnilo turbulentné prostredie na agrotrhu, meniace sa pravidlá finančnej podpory, ale aj v sociálnoekonomická oblast' života na Slovensku. V súčasnom období len v menšej časti agropotravinárstva možno konštatovat', že podnikové manažmenty plnohodnotne aplikujú marketingové postupy. [6] S postupným vstupom zahraničných spoločností do slovenských potravinárskych podnikov pozorujeme zvyšovanie opodstatnenosti marketingového riadenia vo vzt'ahu $\mathrm{k}$ úspešnosti na trhu. Marketingové prístupy $\mathrm{k}$ manažmentu podniku sú významným predpokladom úspešnosti podnikania.

Úspech podnikatel'ského subjektu závisí od mnohých faktorov a podmienok, medzi ktorými na popredné miesto radíme kvalitné marketingové riadenie v dynamicky sa meniacom prostredí. Marketingové riadenie je systematická ciel'avedomá činnost' zameraná na maximálne využitie možností a schopností podniku s ciel'om získat' stabilné postavenie na trhu a konkurenčnú výhodu pri uspokojovaní potrieb zákazníkov. V súčasných podmienkach globalizácie a integrácie trhových štruktúr dochádza k teritoriálnemu rozšíreniu pôsobnosti marketingového riadenia na nové ciel'ové trhy. [5]

Na základe identifikovaných požiadaviek a želaní podnik následne kreuje najvhodnejšiu marketingovú stratégiu, ktorou sa chce presadit' na danom trhu. Zvolená marketingová stratégia sa zhmotňuje v marketingovom mixe. Z praktického pohl'adu závisí úspešné nasadenie marketingového mixu predovšetkým od splnenia troch podmienok [3]:

$\checkmark$ nástroje marketingového mixu musia $\mathrm{v}$ časovom priebehu tvorit’ konštantný a harmonický celok,

$\checkmark$ vybavenie nástrojov marketingového mixu má odrážat' danosti, prípadne vývoj trhu a situáciu v podniku,

$\checkmark$ intenzita nasadenia jednotlivých nástrojov marketingového mixu musí byt' dostatočne vel'ká.

Náročnost' uvedeného postupu spočíva $\mathrm{v}$ tom, že menované podmienky sa $\mathrm{v}$ priebehu času menia a vzájomne sa ovplyvňujú.

Najnovšie trendy v marketingu poukazujú na tú skutočnost', že marketing predstavuje integrovaný komplex činností zameraných na spotrebitel'ov a trh. Marketingové činnosti musia byt' zároveň previazané s ostatnými procesmi v podnikatel'skom subjekte a integrálnou súčast'ou manažmentu.

Marketingový manažment je nepretržitým procesom analýzy, plánovania, implementácie a kontroly. Jeho zmyslom je vytvorenie a udržanie dlhodobých vzt'ahov s ciel'ovými zákazníkmi a spotrebitel'mi, ktoré umožnia podnikom dosiahnut' stanovené ciele. [2]. Ciel’om marketingového manažmentu je identifikovat' potreby a želania spotrebitel'a, vytvorit' predstavu o inovatívnom produkte a nastavit' podnikové procesy tak, aby podnik ponúkol kvalitnejší a efektívnejší produkt v porovnaní s konkurenciou. 
Postupujúca globalizácia svetovej ekonomiky a integračné procesy spôsobujú, že podnikatel'ské subjekty čoraz vo väčšej miere realizujú podnikanie v medzinárodnom prostredí, prenikajú na zahraničné trhy za účelom lepšieho zhodnocovania podnikového kapitálu a sú vystavené extrémnemu konkurenčnému tlaku. [4]

\section{Výsledky a diskusia}

Integrácia Slovenska do trhových štruktúr Európskej únie bol okrem pozitívnych stránok vnímaný zo strany podnikatel'ského sektora aj negatívne. Z agropotravinárskych podnikov to platí takmer pre všetky spracovatel'ské podniky. Na jednej strane sa pre slovenské podniky otvorila možnost' jednoduchšie vstúpit' na trh únie, ale na druhej strane bolo nutné splnit' náročné podmienky hygienických, kvalitatívnych a veterinárnych noriem. Vysoká úroveň týchto parametrov mala za následok okrem iného aj zánik mnohých podnikov, ktoré sa nedokázali prispôsobit' zmeneným podmienkam. Splnenie kritérií jednotlivých noriem si vyžiadala finančne náročné investície do technologického vybavenia a rekonštrukcie existujúcich výrobných podnikov.

Prispôsobovanie mäsospracujúcich podnikov novým legislatívnym a trhovým podmienkam bol prvým nevyhnutným predpokladom úspešného podnikania na vnútornom trhu EÚ. Túto formu prispôsobovania nazývame ako povinnú adaptáciu, ktorá umožňuje konkrétnym podnikatel'ským subjektom vykonávat' podnikatel'skú činnost'v agropotravinárstve. [1]

Európska únia predstavuje podnikatel'ské prostredie s medzinárodnými, nadnárodnými a národnými črtami. Niektoré právne, politické, ekonomické a technologické faktory marketingového mixu členských krajín únie nemajú ani jednoznačný medzinárodný alebo národný charakter, sú skôr kombináciou národných a nadnárodných noriem, pravidiel a politík. Predmetom marketingového manažmentu podnikov integrovaných ekonomík sú predovšetkým orientácia na vysokú kvalitu produkcie, jej konkurencieschopnost' a presadenie sa na jednotnom európskom trhu a zároveň strategický marketingový manažment zameraný na výrobkovú diferenciáciu a zvýšenie nadhodnoty pri produktoch. Túto oblast' marketingového manažmentu môžeme považovat' za dobrovol'nú formu adaptácie na nové podmienky za účelom získat' konkurenčnú výhodu a väčší podiel na trhu. Na konkrétnom podniku záleží, akú marketingovú stratégiu zvolí pre dosiahnutie vytýčených ciel’ov.

Objektom skúmania bolo 9 najväčších podnikov, určených na výrobu živočíšnych produktov na území Slovenska, ktoré svojou produkciou pokrývajú 74,8\% ponuky trhu. Údaje získané výskumom považujeme za prípadovú štúdiu. V centre našej pozornosti sú vybrané marketingovo-manažérske a ekonomické ukazovatele. Sekundárne údaje boli získané zo Štatistického úradu SR. Tabul'ka 1 prezentuje najväčších spracovatel'ov mäsa v analyzovanom období 2002 - 2006 na Slovensku podl'a údajov zo Štatistického úradu SR [7] a Zelenej správy [8].

Ako je z tabul'ky 1 zrejmé, najväčším a zároveň najúspešnejším podnikatel'ským subjektom v mäsospracujúcom priemysle v období rokov 2002 - 2006 bola spoločnost' Tauris, a. s. Dlhodobo si udržiava vedúci pozíciu vd’aka premyslenej podnikatel'skej stratégii, inováciám a efektívnemu marketingovému riadeniu. Druhý a tretí najvýznamnejší subjekt - Hrádok Mäsokombinát, a. s. a Mecom, a. s. si udržujú svoje pozície stabilne. Spoločnost' THP, a. s. a Hyza, a. s. začali zaostávat' za vedúcimi spracovatel'skými podnikmi a ako samostatné 
subjekty nedokázali efektívne obstát' v konkurenčnom boji, čo vyústili v roku 2007 k ich zlúčeniu do jedného subjektu.

Tabul'ka $1 \quad$ Najväčšie mäsospracujúce podniky na Slovensku

\begin{tabular}{|c|c|c|c|c|c|}
\hline $\begin{array}{l}\text { Por. } \\
\text { Č. }\end{array}$ & 2002 & 2003 & 2004 & 2005 & 2006 \\
\hline 1. & Tauris, a. s. & Tauris, a. s. & Tauris, a. s. & Tauris, a. s. & Tauris, a. s. \\
\hline 2. & $\begin{array}{c}\text { Hrádok } \\
\text { Mäsokombinát, } \\
\text { s.r.o. }\end{array}$ & $\begin{array}{c}\text { Hrádok } \\
\text { Mäsokombinát, } \\
\text { s.r.o. }\end{array}$ & $\begin{array}{c}\text { Hrádok } \\
\text { Mäsokombinát } \\
\text { s.r.o. }\end{array}$ & Mecom, a. s. & Mecom, a. s. \\
\hline 3. & Mecom, a. s. & Mecom, a. s. & Mecom, a. s. & $\begin{array}{c}\text { Hrádok } \\
\text { Mäsokombinát, } \\
\text { s.r.o. }\end{array}$ & THP, a. s. \\
\hline 4. & THP, a. s. & THP, a. s. & THP, a. s. & $\begin{array}{l}\text { PM Zbrojníky, } \\
\text { a. s. }\end{array}$ & $\begin{array}{c}\text { Hrádok } \\
\text { Mäsokombinát, } \\
\text { s.r.o. }\end{array}$ \\
\hline 5. & Hyza, a. s. & $\begin{array}{l}\text { PM Zbrojníky, } \\
\text { a. s. }\end{array}$ & $\begin{array}{l}\text { PM Zbrojníky, } \\
\text { a. s. }\end{array}$ & THP, a. s. & $\begin{array}{l}\text { PM Zbrojníky, } \\
\text { a. s. }\end{array}$ \\
\hline 6. & Hydina ZK, a. s. & $\begin{array}{l}\text { Tauris Danubius, a. } \\
\text { s. }\end{array}$ & $\begin{array}{c}\text { Tauris Danubius, } \\
\text { a. s. }\end{array}$ & $\begin{array}{c}\text { Tauris Danubius, } \\
\text { a. s. }\end{array}$ & Hyza, a. s. \\
\hline 7. & $\begin{array}{c}\text { Tauris } \\
\text { Danubius, a. s. }\end{array}$ & Hyza, a. s. & Hyza, a. s. & Hyza, a. s. & $\begin{array}{c}\text { Tauris } \\
\text { Danubius, a. s. }\end{array}$ \\
\hline 8. & Hydina, a. s. & Hydina ZK, a. s. & Hydina ZK, a. s. & Hydina ZK, a. s. & Hydina ZK, a. s. \\
\hline
\end{tabular}

Zdroj: Štatistický úrad SR, vlastné spracovanie

Za účelom identifikovania silných stránok a príležitostí, ako aj slabých stránok a hrozieb sme uskutočnili SWOT analýzu v súbore skúmaných mäsospracujúcich podnikov. Súhrnný prehl'ad o situácii v jednotlivých podnikoch dokumentuje tabul'ka 2. Podnikatel'ské subjekty, ktoré boli zúčastnené na výskume, reagovali na zmeny v ich makroprostredí a postupne sa prispôsobovali novým socio-ekonomickým podmienkam. Skúmané podniky nielen zaviedli, ale aj nad'alej udržujú výrobný proces podl'a prísnych podmienok systému kritických bodov HACCP. Okrem tohto systému majú implementovaný systém manažmentu kvality podl'a noriem ISO radu 9001, resp. radu 9002. Výskum preukázal časový sklz v implementácií systémov riadenia kvality u jednotlivých podnikov, z ktorého pre niektoré subjekty vyplynula konkurenčná výhoda. Pružné v zavedení systému kvality podl'a ISO noriem boli Podnik 1, Podnik 3 a Podnik 7 a stali sa tak lídrami na trhu s primeraným nárastom objemu tržieb.

Prispôsobovanie sa náročným technologickým normám si vyžiadalo vysoké investície do nákupu a zavedení nových technológií a technologických postupov pri spracovaní mäsa na mäsové produkty. Investičné aktivity podniky zabezpečovali prostredníctvom úverových liniek, čím sa na druhej dochádzalo k vysokej finančnej a kapitálovej zadíženosti (Podnik 2, Podnik 5, Podnik 7). Príležitost' získat' zadlžené podniky podnietili finančné skupiny (Penta Investments, a. s. a EcoInvest, a. s.) vstúpit' do podnikania v agropotravinárstve. 
Tabul'ka 2 Niektoré aspekty marketingového mixu a SWOT analýzy

\begin{tabular}{|c|c|c|c|c|}
\hline & Podnik 1 & Podnik 2 & Podnik 3 & Podnik 4 \\
\hline $\begin{array}{c}\text { Produktové } \\
\text { portfólio }\end{array}$ & $\begin{array}{l}132 \text { druhov } \\
\text { produktov }\end{array}$ & $\begin{array}{l}252 \text { druhov } \\
\text { produktov }\end{array}$ & $\begin{array}{l}224 \text { druhov } \\
\text { produktov }\end{array}$ & $\begin{array}{l}110 \text { druhov } \\
\text { produktov }\end{array}$ \\
\hline Systém & ISO $9001-2003$ & ISO $9001-2003$ & ISO $9001-1998$ & ISO $9001-2002$ \\
\hline manažérstva & SK 15 - 1996 & SK 6061 - 2004 & ISO 9002 - 1998 & ISO 14001 - 2006 \\
\hline kvality a rok & SK 5 - 2001 & & BRC Food - 2003 & SK 61 - 2003 \\
\hline $\begin{array}{c}\text { implementáci } \\
\text { e }\end{array}$ & SK 618 - 2004 & & $\begin{array}{c}\text { IFS - } 2003 \\
\text { SK } 63-2003\end{array}$ & \\
\hline НАССР & od r. 1997 & od r. 1998 & od r. 2004 & od r. 2001 \\
\hline $\begin{array}{c}\text { Dynamika } \\
\text { tržieb }\end{array}$ & $\begin{array}{l}\text { 107,5 mil. } €-107,9 \\
\text { mil. } € \uparrow\end{array}$ & $\begin{array}{l}75,6 \text { mil. } €- \\
63,0 \text { mil. } € \downarrow\end{array}$ & $\begin{array}{l}54,8 \text { mil. } €- \\
81,3 \text { mil. } € \uparrow\end{array}$ & $\begin{array}{l}\text { 70,3 mil. } €- \\
38,6 \text { mil. } € \downarrow\end{array}$ \\
\hline Silné stránky & $\begin{array}{c}\text { moderná } \\
\text { technológia, } \\
\text { produktová } \\
\text { inovatívnost', } \\
\text { kvalifikované } \\
\text { l'udské zdroje, } \\
\text { dlhodobé vzt'ahy } \\
\text { s obchodnými } \\
\text { ret’azcami }\end{array}$ & $\begin{array}{c}\text { moderná } \\
\text { technológia, } \\
\text { kvalifikované } \\
\text { l'udské zdroje, } \\
\text { originálne } \\
\text { receptúry, priaznivá } \\
\text { geografická poloha } \\
\text { k zahraničným } \\
\text { trhom, } \\
\text { vlastný bitúnok }\end{array}$ & $\begin{array}{c}\text { skúsený } \\
\text { manažment } \\
\text { podniku, } \\
\text { strategický } \\
\text { marketing, } \\
\text { investície do } \\
\text { technológií, } \\
\text { rozšírenie } \\
\text { výrobných kapacít, } \\
\text { akvizície s malými } \\
\text { podnikmi }\end{array}$ & $\begin{array}{l}\text { kvalifikované } \\
\text { l'udské zdroje, } \\
\text { vlastná prevádzka } \\
\text { konzervárne }\end{array}$ \\
\hline Slabé stránky & $\begin{array}{c}\text { kapitálová } \\
\text { zadlženost', } \\
\text { nevhodná } \\
\text { kapitálová štruktúra }\end{array}$ & $\begin{array}{l}\text { v obchodných } \\
\text { ret’azcoch len užší } \\
\text { sortiment, reklama }\end{array}$ & $\begin{array}{l}\text { duplicita riadenia, } \\
\text { nevhodná } \\
\text { organizačná } \\
\text { a riadiaca štruktúra }\end{array}$ & $\begin{array}{c}\text { sporadický } \\
\text { marketing, absencia } \\
\text { manažérskych } \\
\text { skúseností }\end{array}$ \\
\hline Príležitosti & $\begin{array}{c}\text { prienik na } \\
\text { zahraničné trhy, } \\
\text { fondy EÚ, zvýšenie } \\
\text { dôvery } \\
\text { spotrebitel'ov }\end{array}$ & $\begin{array}{c}\text { prienik na } \\
\text { zahraničné trhy, } \\
\text { posilnenie } \\
\text { reklamnej činnosti, } \\
\text { širšie produktové } \\
\text { portfólio } \\
\text { v obchodných } \\
\text { ret’azcoch }\end{array}$ & $\begin{array}{c}\text { prienik na } \\
\text { zahraničné trhy, } \\
\text { inovácie } \\
\text { v produktovom } \\
\text { portfóliu }\end{array}$ & $\begin{array}{c}\text { prienik na } \\
\text { zahraničné trhy, } \\
\text { koncentrácia } \\
\text { v odvetví, akvizície } \\
\text { podnikov } \\
\text { nespíňajúce normy } \\
\text { EÚ }\end{array}$ \\
\hline Hrozby & $\begin{array}{l}\text { prevádzkové } \\
\text { náklady, tlak } \\
\text { obchodných } \\
\text { ret’azcov na cenu } \\
\text { a tým znižovanie } \\
\text { kvality produktov, } \\
\text { konkurenčný boj }\end{array}$ & $\begin{array}{l}\text { prevádzkové } \\
\text { náklady, pokles } \\
\text { reálnych príjmov } \\
\text { spotrebitel'ov }\end{array}$ & $\begin{array}{c}\text { prevádzkové } \\
\text { náklady, } \\
\text { konkurenčný boj }\end{array}$ & $\begin{array}{c}\text { prevádzkové } \\
\text { náklady, } \\
\text { konkurenčný boj, } \\
\text { tlak obchodných } \\
\text { ret'azcov na cenu } \\
\text { a tým znižovanie } \\
\text { kvality produktov }\end{array}$ \\
\hline Propagácia & $\begin{array}{l}\text { aktívna propagácia } \\
\text { formou účasti na } \\
\text { výstavách doma } \\
\text { a v zahraničí }\end{array}$ & $\begin{array}{l}\text { aktívna propagácia } \\
\text { formou účasti na } \\
\text { výstavách doma } \\
\text { a v zahraničí }\end{array}$ & $\begin{array}{l}\text { aktívna propagácia } \\
\text { formou účasti na } \\
\text { výstavách doma } \\
\text { a v zahraničí }\end{array}$ & $\begin{array}{l}\text { aktívna propagácia } \\
\text { formou účasti na } \\
\text { výstavách doma } \\
\text { a v zahraničí }\end{array}$ \\
\hline
\end{tabular}

Zdroj: primárny výskum, vlastné spracovanie

Tabul'ka 2 a 3 poskytuje syntetický prehl'ad o situácii v jednotlivých podnikatel'ských subjektoch a dáva ucelenú informáciu o produktoch, certifikátoch kvality, dynamike tržieb, silných a slabých stránkach spoločností vrátane identifikácie príležitostí a hrozieb z pohl’adu konkrétneho podniku. 
Tabul'ka 3 Niektoré aspekty marketingového mixu a SWOT analýzy v d'alších podnikoch

\begin{tabular}{|c|c|c|c|c|c|}
\hline & Podnik 5 & Podnik 6 & Podnik 7 & Podnik 8 & Podnik 9 \\
\hline $\begin{array}{l}\text { Produktové } \\
\text { portfólio }\end{array}$ & $\begin{array}{l}100 \text { druhov } \\
\text { produktov }\end{array}$ & $\begin{array}{l}190 \text { druhov } \\
\text { produktov }\end{array}$ & $\begin{array}{l}40 \text { druhov } \\
\text { produktov }\end{array}$ & $\begin{array}{l}\text { porážka } \\
\text { a rozrábka } \\
\text { mäsa }\end{array}$ & $\begin{array}{l}40 \text { druhov } \\
\text { produktov }\end{array}$ \\
\hline $\begin{array}{c}\text { Systém } \\
\text { manažérstva } \\
\text { kvality a rok } \\
\text { implementácie }\end{array}$ & $\begin{array}{c}\text { ISO } 9001- \\
2000 \\
\text { SK } 64-2004\end{array}$ & $\begin{array}{c}\text { ISO } 9001- \\
2004 \\
\text { SK } 3092- \\
2004\end{array}$ & $\begin{array}{c}\text { ISO } 9002- \\
1996 \\
\text { SK } 15-1996\end{array}$ & $\begin{array}{c}\text { SK 26 - } \\
1997\end{array}$ & $\begin{array}{c}\text { ISO } 9001-2004 \\
\text { SK } 630 \mathrm{ES}- \\
2004 \\
\text { SK } 3031-2004\end{array}$ \\
\hline НАCCP & od r. 1998 & od r. 2004 & od r. 1995 & od r. 1999 & od r. 2000 \\
\hline $\begin{array}{c}\text { Dynamika } \\
\text { tržieb }\end{array}$ & $\begin{array}{c}256 \text { mil. } €-430 \\
\text { mil. } € \uparrow\end{array}$ & $\begin{array}{l}95 \text { mil. } €- \\
161 \text { mil. } € \uparrow\end{array}$ & $\begin{array}{l}373 \text { mil. } €- \\
336 \text { mil. } € \downarrow\end{array}$ & - & $\begin{array}{c}140-484 \text { mil. } € \\
\uparrow\end{array}$ \\
\hline Silné stránky & $\begin{array}{c}\text { kvalita } \\
\text { produktov, } \\
\text { vlastná siet' } \\
\text { maloobchodov, } \\
\text { kapitálové } \\
\text { prepojenie } \\
\text { s podnikom } 1\end{array}$ & $\begin{array}{c}\text { flexibilita } \\
\text { adaptácie } \\
\text { a pružnost' } \\
\text { na regionálne } \\
\text { zmeny, } \\
\text { dostupné } \\
\text { ceny, } \\
\text { individuálny } \\
\text { prístup }\end{array}$ & $\begin{array}{l}\text { obal a inovácie } \\
\text { produktov, } \\
\text { kapitálové } \\
\text { prepojenie } \\
\text { s podnikom } 1\end{array}$ & $\begin{array}{l}\text { dostupné } \\
\text { ceny, } \\
\text { moderná } \\
\text { technológia, } \\
\text { výroba } \\
\text { biomäsa }\end{array}$ & $\begin{array}{l}\text { kvalita produktov, } \\
\text { flexibilita, } \\
\text { kvalifikované } \\
\text { l'udské zdroje, } \\
\text { vlastný bitúnok, } \\
\text { výroba biomäsa }\end{array}$ \\
\hline Slabé stránky & $\begin{array}{c}\text { absencia } \\
\text { marketingových } \\
\text { činností }\end{array}$ & $\begin{array}{l}\text { iba lokálne } \\
\text { podnikanie, } \\
\text { slabá } \\
\text { marketingov } \\
\text { á politika }\end{array}$ & $\begin{array}{l}\text { vysoké } \\
\text { prevádzkové } \\
\text { (osobitne } \\
\text { finančné) } \\
\text { náklady, } \\
\text { absencia } \\
\text { exportu }\end{array}$ & $\begin{array}{c}\text { iba výsekové } \\
\text { mäso, } \\
\text { fluktuácia } \\
\text { l'udských } \\
\text { zdrojov }\end{array}$ & $\begin{array}{l}\text { absencia exportu, } \\
\text { úzky sortiment, } \\
\text { slabá } \\
\text { marketingová } \\
\text { politika }\end{array}$ \\
\hline Príležitosti & $\begin{array}{c}\text { intenzívne } \\
\text { využitie } \\
\text { kapitálového } \\
\text { prepojenia } \\
\text { s podnikom1, } \\
\text { prienik na } \\
\text { zahraničné trhy, } \\
\text { nové } \\
\text { hypermarkety }\end{array}$ & $\begin{array}{l}\text { prienik na } \\
\text { zahraničné } \\
\text { trhy, } \\
\text { reklama, } \\
\text { fondy EÚ }\end{array}$ & $\begin{array}{c}\text { prienik na } \\
\text { zahraničné trhy, } \\
\text { reklama, } \\
\text { fondy EÚ }\end{array}$ & $\begin{array}{l}\text { prienik na } \\
\text { zahraničné } \\
\text { trhy, } \\
\text { reklama, } \\
\text { fondy EÚ }\end{array}$ & $\begin{array}{c}\text { prienik na } \\
\text { zahraničné trhy, } \\
\text { reklama }\end{array}$ \\
\hline Hrozby & $\begin{array}{l}\text { konkurenčný } \\
\text { boj, úplné } \\
\text { podriadenie } \\
\text { obchodnej } \\
\text { politiky podniku } \\
1\end{array}$ & $\begin{array}{l}\text { konkurenčný } \\
\text { boj }\end{array}$ & $\begin{array}{l}\text { prevádzkové } \\
\text { náklady, } \\
\text { konkurenčný } \\
\text { boj, tlak } \\
\text { obchodných } \\
\text { ret’azcov }\end{array}$ & $\begin{array}{c}\text { tlak } \\
\text { obchodných } \\
\text { ret'azcov, } \\
\text { prevádzkové } \\
\text { náklady }\end{array}$ & $\begin{array}{l}\text { prevádzkové } \\
\text { náklady, tlak } \\
\text { obchodných } \\
\text { ret’azcov, } \\
\text { konkurenčný boj }\end{array}$ \\
\hline Propagácia & pasívna účast' & $\begin{array}{l}\text { pasívna } \\
\text { účast' }\end{array}$ & $\begin{array}{c}\text { aktívna } \\
\text { propagácia } \\
\text { formou účasti } \\
\text { na výstavách } \\
\text { doma } \\
\text { a v zahraničí }\end{array}$ & $\begin{array}{l}\text { pasívna } \\
\text { účast' }\end{array}$ & pasívna účast' \\
\hline
\end{tabular}

Zdroj: primárny výskum, vlastné spracovanie

Syntézou zistených skutočností z vypracovanej SWOT analýzy identifikujeme v časti výberového súboru absenciu prvkov strategického marketingového manažmentu, v jednom prípade absenciu stratégie rozvoja l’udských zdrojov s nedostatočnou motiváciou, dve pätiny podnikov nevyužívajú aktívne možnosti komunikačného mixu a žiaden podnik v skúmanom období nevstúpil na nový zahraničný trh. Z potenciálnych hrozieb sú to nákazlivé choroby zvierat (BSE, KMO), nízka obchodná marža v mäsopriemysle, vymožitel'nost' práva, 
nedostatočná ochrana domáceho trhu. Rizikovými faktormi ostávajú aj zvyšujúce sa ceny energií, vstupných surovín a pokles kúpyschopnosti obyvatel'stva. Manažmenty podnikatel'ských subjektov sa zhodujú v názore, že pod vplyvom vstupu Slovenska do Európskej únie došlo k vyostreniu domácej i zahraničnej konkurencie a pocit’ujú nedostatočnú ochranu domáceho trhu pred zahraničnými dodávatel'mi. Diskriminačné zvyklosti zahraničných obchodných ret’azcov sa prejavuje zneužívaním svojho dominantného postavanie a narastajúcou silou voči spracovatel'om.

Silné stránky predstavujú pozitívne faktory, ktoré sú významné pre budúcu podnikatel'skú úspešnost' a v súbore analyzovaných podnikov ide o: implementovaný systém manažmentu kvality, moderné technologické vybavenie, kvalitné a inovované produkty, kapitálová previazanost' podnikov s prvovýrobou. Pri zavádzaní systémov kvality vidíme časové rozdiely pri ich získaní, z čoho vyplynula konkurenčná výhoda pre skôr certifikované podniky. Na druhej strane nákup moderných technologických zariadení vyvolalo finančné zadíženie niektorých subjektov a následne ich prevzatie silnejšími subjektmi. Z príležitostí uvádzame nové distribučné kanály (nákupné aliancie, hypermarkety), nákupné zvyklosti spotrebitel'ov (balené mäso, mäsové polotovary), internacionalizácia podnikania a prienik na zahraničné trhy, posilnenie marketingových aktivít.

Zostrený konkurenčný boj na trhu sa prejavuje aj v dynamike tržieb skúmaných podnikov. Zaujímali sme sa o vývoj celkových tržieb za obdobie 2002 - 2006. Na základe zistení uvádzame, že rast zaznamenalo šest' subjektov $(66,66 \%)$, stagnáciu dva podniky $(22,22 \%)$ a pokles tržieb jeden podnikatel'ský subjekt $(11,11 \%)$.

Prostredníctvom zostaveného dotazníka sme zist'ovali, aké zmeny vobjeme tržieb zaznamenali podniky pri predaji produktov pod privátnymi značkami. Testovali sme hypotézu:

$\mathrm{H}_{0}$ : Predpokladáme, že neexistuje závislost' medzi podielom predaja na zahraničnom trhu a predajom pod privátnymi značkami.

$\mathrm{H}_{1}$ : Predpokladáme, že existuje závislost' medzi podielom predaja na zahraničnom trhu a predajom pod privátnymi značkami.

Hypotézu sme overovali chí-kvadrát testom nezávislosti. Silu závislosti sme zist'ovali Pearsonovým kontingenčným koeficientom C. Výsledky uvádzame v tabul'ke 4.

Tabul'ka 4 Testovanie závislostí

\begin{tabular}{||c||c||c||c||}
\hline Názov testu & Test & Statistika & P-hodnota \\
\hline \hline Test nezávislosti & Chí-kvadrát & 18,7682 & 0.0009 \\
\hline \hline Sila závislosti & $\begin{array}{c}\text { Kontingenčný } \\
\text { koeficient }\end{array}$ & - & 0.7145 \\
\hline
\end{tabular}

Zdroj: primárny výskum, výstup zo software SAS

Vypočítaná hodnota testovacieho kritéria $\chi^{2}$ je väčšia ako kritická hodnota $\chi_{\text {tab }}$, zamietame teda hypotézu $\mathrm{H}_{0}$ a prijímame hypotézu $\mathrm{H}_{1}$, podl'a ktorej závislost' medzi uvedenými 
kvalitatívnymi znakmi existuje. Na základe hodnoty Pearsonovho kontingenčného koeficientu môžeme tvrdit', že ide o vel'mi silnú závislost'. Výroba produktov pod privátnymi značkami ako aj expanzia na zahraničných trhoch znamenajú vel'kú adaptibilitu podniku na pôsobenie v silnom konkurenčnom prostredí a využitie potenciálnych možností presadenia sa na trhu.

V d’alšej časti výskumu sme sa zaujímali o typy obchodov, ktoré sa v skúmanom horizonte období najväčšou mierou podiel’ajú na predaji produktov. Výsledky prezentuje graf 1.

Graf 1 Typy obchodov, ktoré sa najväčšou mierou podiel'ajú na predaji produktov

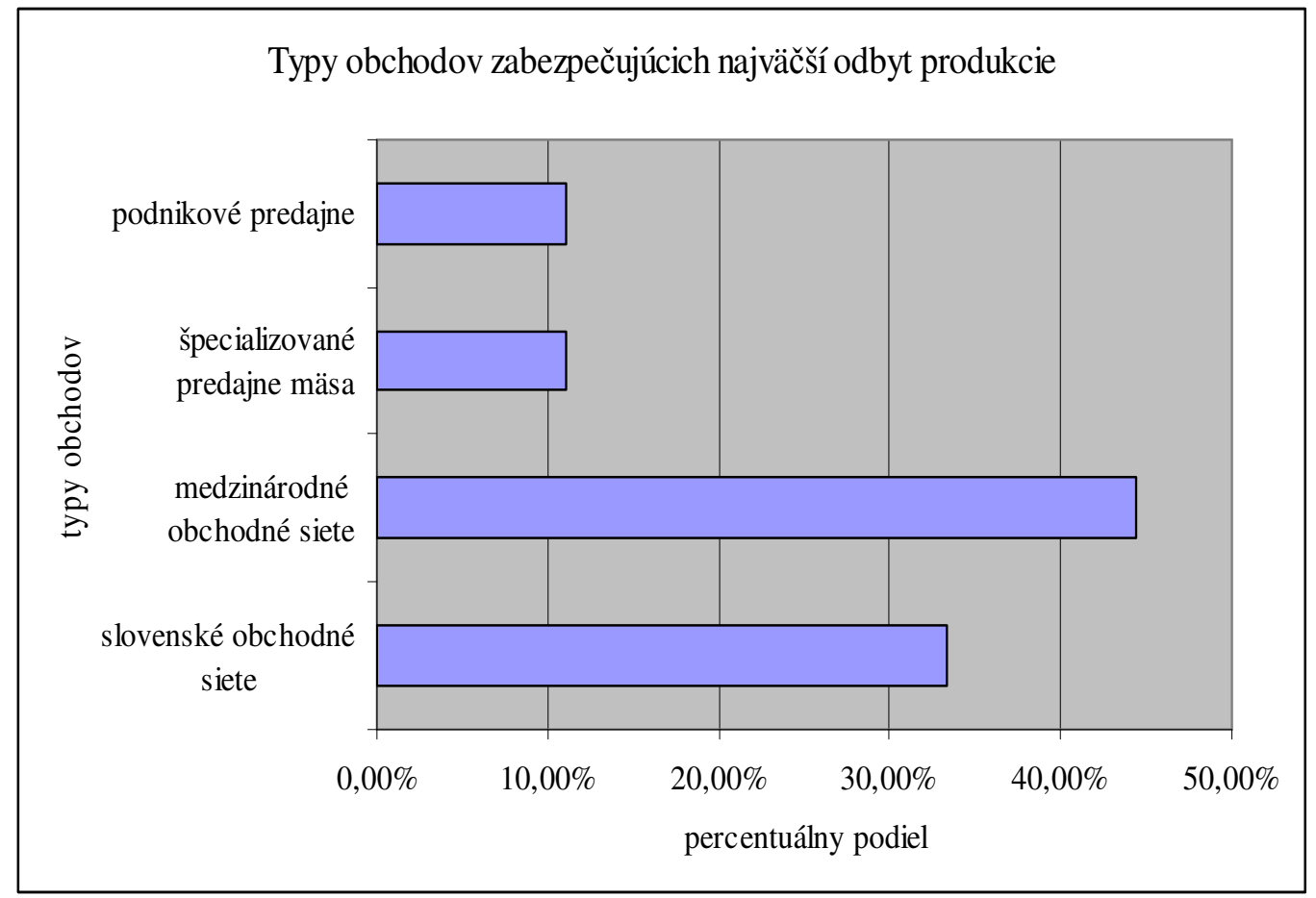

Zdroj: primárny výskum, vlastné spracovanie

Ako je z grafu 1 zrejmé, najväčšia čast' produkcie je predaná cez medzinárodné obchodné siete. Robia tak 4 podniky s podielom $44,44 \%$. Vd'aka uvedenému typu obchodov sa produkcia slovenských mäsospracujúcich podnikov dostáva aj na zahraničné trhy. To umožňuje podnikatel'ských subjektom zabezpečit' predaj väčšieho objemu produkcie, zvýšit' ziskovost' podnikania a budovanie si perspektívneho postavenia na ciel'ových trhoch. Ojedenást' percentuálnych bodov menej sa na predaji produkcie podiel'ajú slovenské obchodné siete - je tak v prípade 3 podnikov. Rovnakým podielom - 11,11\% sa na zabezpečení odbytu podiel'ajú špecializované predajne mäsa a podniková predajňa. V oboch prípadoch ide o $1-1$ podnik. Aj ked' špecializované a podnikové predajne zabezpečujú iba malý podiel na predaji, umožňujú ponúkat' svojim zákazníkom celý sortiment príslušného podniku, rovnako i produkty s vyššou pridanou hodnotou.

Vstup Slovenska do Európskej únie znamenal pre slovenské podniky možnost' presadit' sa aj na zahraničných trhoch členských krajín únie, ale na druhej strane sa výrazne akcelerovala konkurencia. Zist'ovali sme teda, či existuje závislost' medzi zvýšenou domácou konkurenciou po vstupe do EÚ a väčším dôrazom kladeným po vstupe do únie na kvalitu a dodržiavanie kvalitatívnych noriem. Testovali sme hypotézu: 
$\mathrm{H}_{0}$ : Predpokladáme, že neexistuje závislost' medzi zvýšenou domácou konkurenciou po vstupe do EÚ a väčším dôrazom kladeným po vstupe do únie na kvalitu a dodržiavanie kvalitatívnych noriem.

$\mathrm{H}_{1}$ : Predpokladáme, že existuje závislost' medzi zvýšenou domácou konkurenciou po vstupe do EÚ a väčším dôrazom kladeným po vstupe do únie na kvalitu a dodržiavanie kvalitatívnych noriem

Hypotézu sme overovali chí-kvadrát testom nezávislosti. Vzhl'adom na výsledok výpočtov nebola zist'ovaná sila závislosti. Výsledky uvádzame v tabul'ke 5.

Tabul'ka 5 Testovanie závislostí

\begin{tabular}{||c||c||c||c||}
\hline Názov testu & Test & Štatistika & P-hodnota \\
\hline \hline Test nezávislosti & Chí-kvadrát & 1,1688 & 0.2796 \\
\hline \hline Sila závislosti & $\begin{array}{c}\text { Kontingenčný } \\
\text { koeficient }\end{array}$ & - & - \\
\hline
\end{tabular}

Zdroj: primárny výskum, výstup zo software SAS

Vypočítaná hodnota testovacieho kritéria $\chi^{2}$ je nižšia ako kritická hodnota $\chi_{\text {tab }}$, prijímame teda hypotézu $\mathrm{H}_{0}$, podl'a ktorej závislost' medzi uvedenými kvalitatívnymi znakmi neexistuje a zamietame hypotézu $\mathrm{H}_{1}$. Znamená to teda, že podniky zvýšená konkurencia na trhu pod vplyvom vstupu Slovenska do Európskej únie počas skúmaného obdobia preukázatel'ne nemotivovala klást' väčší dôraz na zabezpečenie kvality svojej produkcie. Z hl'adiska budúcej perspektívy odporúčame podnikom prehodnotit' možný dopad zostrujúcej sa konkurencie na ich podnikatel'skú činnost' a aktívne sa podiel'at' na budovaní svojej pozície na trhu.

V rámci analýzy marketingového manažmentu v skúmanom súbore mäsospracujúcich podnikov sme sa podnikatel'ské subjekty pýtali na vplyv jednotlivých marketingových opatrení na zvýšenie objemu tržieb, pritom respondenti mohli jednotlivým faktorom pridelit' body na stupnici 1 až 10. Najnižší vplyv mal hodnotu 1, naopak najvyšší vplyv hodnotu 10. Podniky prirad'ovali pri hodnotení vplyvu konkrétnych marketingových opatrení na dynamiku (výšku) tržieb rozdielnu dôležitost'. Z uvedeného dôvodu sme na vyhodnotenie použili metódy deskriptívnej štatistiky - miery strednej hodnoty. Zistený stav ilustruje graf 2.

Jednoznačne najvyššie skóre na stupnici hodnotenia dosiahlo marketingové opatrenie „cena, cenové akcie, zníženie ceny“. Podl'a skúmaných podnikov má teda najväčší vplyv na zvýšenie tržieb. Druhé najvýznamnejšie marketingové opatrenie je B2B marketing zahrňujúci dobré vzt'ahy s odberatel'mi, kontakty, obchodné prezentácie. Takmer rovnaký výsledok dosiahol faktor „výroba pod privátnou značkou“. Umožňuje to podnikom prenikat' no iných segmentov trhu. Podl'a skúseností manažmentu medzi vplyvy, ktoré v menšej miere ovplyvňujú zvyšovanie tržieb patria faktory ako reklama, ochutnávka a inovácia produktov. Rozdielne využívanie marketingových opatrení a nástrojov v praxi vedie k diferenciácii ponuky producentov. 
Graf 2 Vplyv marketingových opatrení na dynamiku tržieb

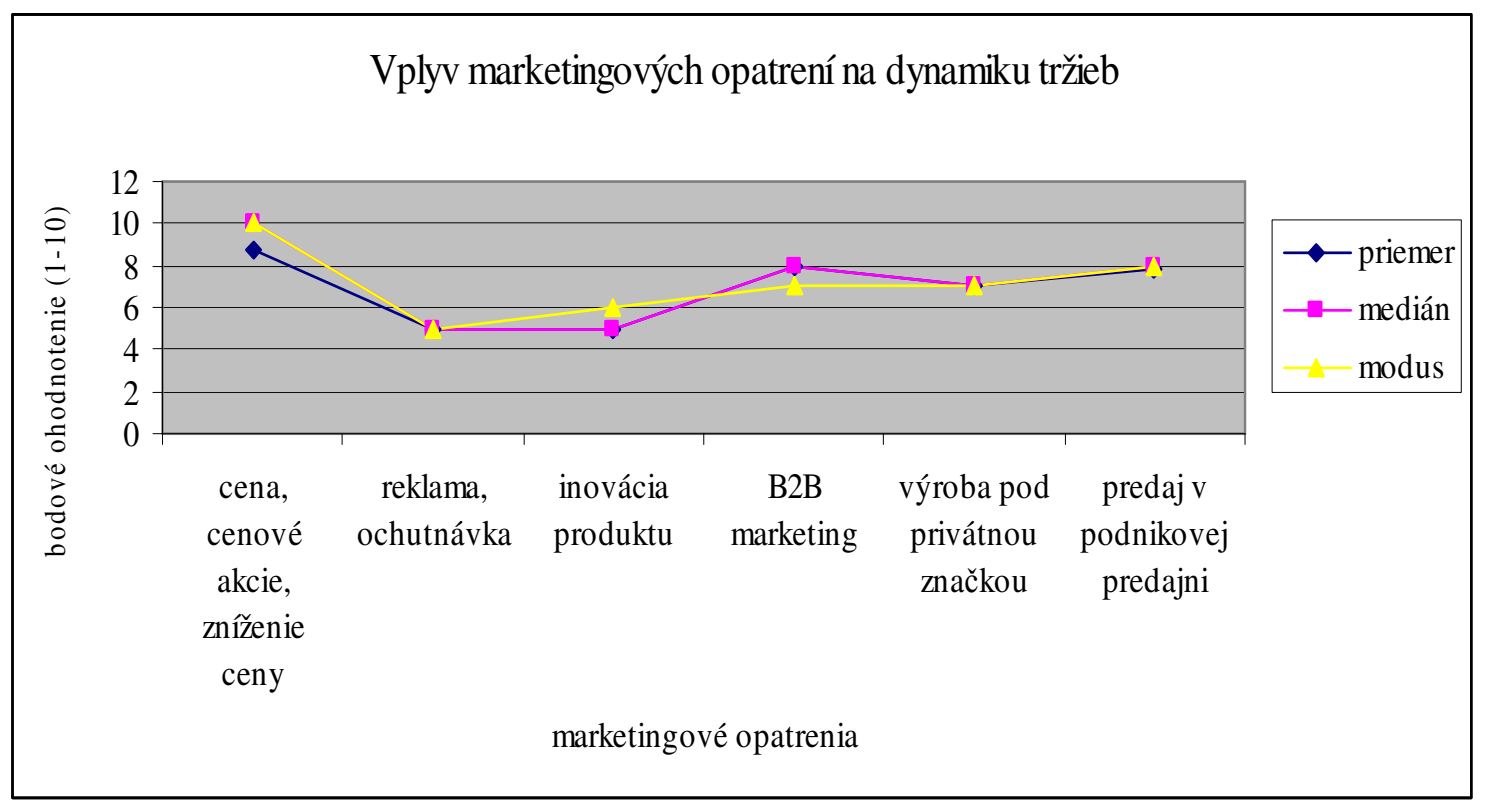

Zdroj: primárny výskum, vlastné spracovanie

\section{Záver}

Odbor spracovania mäsa tvorí významnú zložku v rámci potravinárskeho priemyslu, ked’že svojimi produktmi zabezpečuje nenahraditel'nú výživovú a energetickú zložku potravy obyvatel'ov krajiny. Nemožno ho chápat' izolovane, je integrálnou súčast'ou potravinárstva. Realizovaný výskum odhalil slabú a nedostatočnú previazanost' pol'nohospodárskej prvovýroby s kapacitami spracovatel'ských podnikov a následným predajom v obchodnej sieti. Na základe získaných informácií a uskutočneného výskumu odporúčame zamerat' pozornost' manažmentu podnikov v mäsospracujúcom priemysle na nasledovné oblasti, ktoré považujeme za možné trhové expanzie:

$\checkmark$ produkcia mäsových výrobkov s probiotikami,

$\checkmark$ produkcia mäsových výrobkov so zníženým obsahom tuku,

$\checkmark$ diverzifikácia produktového portfólia,

$\checkmark$ internacionalizácia podnikania, osobitne navrhujeme prienik na trhy krajín V4 a trhy Ruskej federácie,

$\checkmark$ uplatňovat' inovačné stratégie produktov,

$\checkmark$ aktívne rozvíjat' možnosti PR,

$\checkmark$ upevňovat' obchodné vzt'ahy s partnermi prostredníctvom neformálnych stretnutí a spoločných podujatí,

$\checkmark$ rozvíjat' hlbšie B2B marketing,

$\checkmark$ doplńat' l’udské zdroje s jazykovými kompetenciami, skúsenost’ami s podnikaním na zahraničných trhoch.

Identifikácia ciel'ových trhov a jednotlivých trhových segmentov napomáha k splneniu nielen súčasných podnikových ciel'ov, ale aj potenciálnych expanzívnych zámerov. Vybrané aspekty marketingového manažmentu v podnikatel'skej praxi mäsospracujúcich podnikov, perspektívne oblasti pre expanziu determinujú rozhodujúce faktory úspešného prispôsobovania marketingového manažmentu na nové podmienky EÚ. Podl'a Pôdohospodárskej platobnej agentúry [9] je možné do budúcnosti očakávat' vyostrenie 
konkurenčného boja na vnútornom trhu EÚ a krajiny s otvorenou ekonomikou ako Slovensku sa budú musiet' prispôsobovat' importu lacného mäsa a mäsových výrobkov napríklad z Pol'ska a Rumunska.

\section{Literatúra:}

[1] HORSKÁ, E., OREMUS, P. 2008. Territorial Approach to International Marketing Channel and Value Added: Case of Agribusiness. In: Impacts of Globalization on Agribusiness: Trends and Policies, IV. International Conference on Applied Business Research ICABR, ACCRA. Ghana, Publisher: Mendel University in Brno, 2008, ISBN 978-80-7375-154-8

[2] KOTLER, P., ARMSTRONG, G. Marketing. Praha: Grada Publishing, 2004, s. 43 - 47, ISBN 80-247-0513-3

[3] KRETTER, A. a kol. 2010. Marketing. Nitra: SPU, 2010, 288 s., ISBN 978-80-5520355-3

[4] MURA, L. 2010. Penetration of small and medium sized food companies on foreign markets. In: Acta Universitatis Agriculturae et Silviculturae Mendelianae Brunensis, vedecký časopis MZLU Brno, LVIII, 2010, 3, s. 157 - 164, ISSN 1211-8516

[5] OREMUS, P. 2008. Adaptácia marketingového manažmentu podnikov potravinárskeho priemyslu na vnútornom trhu Európskej únie. Nitra: DDP, 2008, $150 \mathrm{~s}$.

[6] ŠIMO, D. 2006. Agrárny marketing. Nitra: SPU, 2006, 300 s., ISBN 80-8069-726-4

[7] ŠÚ SR. Štatistiky. Pol’nohospodárstvo. [online] [cit. 2010-08-11] Dostupné na: http://portal.statistics.sk/showdoc.do?docid=11005

[8] Zelená správa. Správa o pol’nohospodárstve a potravinárstve [online] [cit. 2010-08-08] Dostupné na: http://www.land.gov.sk/sk/?start\&navID=121

[9] Zelené štatistiky. Pôdohospodárska platobná agentúra pri Ministerstve pôdohospodárstva, životného prostredia a regionálneho rozvoja SR. [online] [cit. 2010-08-08] Dostupné na: http://www.apa.sk/index.php?navID=97

\section{JEL klasifikácia: L26 M31 Q13}

\section{Ing. et Bc. Ladislav Mura, Ph.D.}

Odborný asistent

Ústav odborných predmetov a informačných technológií,

Dubnický technologický inštitút

Sládkovičova 533/20, 01841 Dubnica nad Váhom

ladislav.mura@gmail.com 